\title{
Pengaruh Kualitas Pelayanan, Brand Image, dan Kepuasan Pelanggan Terhadap Loyalitas Pelanggan Jasa Transportasi Taksi Blue Bird di Jakarta Barat
}

\author{
Miftakul Huda ${ }^{1}$, Nani Hartati ${ }^{2}$ \\ ${ }^{1,2}$ Program Studi Manajemen \\ ${ }^{1,2}$ Universitas Pelita Bangsa, Jln. Inspeksi Kalimalang Tegal Danas \\ Cikarang Pusat, Bekasi, Jawa Barat \\ Email : miftakulhuda@pelitabangsa.ac.id ${ }^{1}$, nani.hartati@pelitabangsa.ac.id ${ }^{2}$
}

\begin{abstract}
ABSTRAK
Perkembangan Jasa Transportasi di Indonesia semakin meningkat setiap tahunya, hal ini dipengaruhi dengan perkembangan teknologi yang semakin canggih. Kemajuan pesat ini tentunya memberikan dampak perubahan yang signifikan, baik berdampak positif maupun negatif terhadap pelaku usaha lainya. Munculnya transportasi online mampu menggerus pelaku usaha konvensional, Kendati demikian jasa transportasi taksi Blue Bird masih mampu bertahan ditengah pesatnya persaingan di era globalisasi ini.

Penelitian ini bertujuan untuk mengetahui seberapa besar pengaruh Kualitas pelayanan, Brand Image dan Kepuasan Pelanggan terhadap Loyalitas Pelanggan taksi Blue Bird. Jenis penelitian yang digunakan adalah kuantitatif dengan teknik accidental sampling, dengan melibatkan 105 responden pelanggan taksi Blue Bird di mall Ciputra Jakarta Barat. Untuk pengumpulan data meliputi observasi, penyebaran kuesioner dan studi kepustakaan. Metode analisis yang digunakan yaitu uji validitas, uji reliabilitas, uji asumsi klasik, analisis linear berganda dan uji hipotesis.

Pengolahan data menggunakan program SPSS Versi 22.0 dan menghasilkan kesimpulan bahwa kualitas pelayanan (XI) tidak memberikan pengaruh positif dengan nilai signifikan 0,122 lebih besar dari 0.05, variabel Brand Image tidak memberikan pengaruh positif dengan nilai signifikan 0,192 lebih besar dari 0,05 dan variabel Kepuasan Pelanggan memberikan pengaruh positif dengan nilai signifikan 0,002 lebih kecil dari 0,05 .
\end{abstract}

Kata kunci : Kualitas Pelayanan, Brand Imange, Kepuasan Pelanggan dan Loyalitas Pelanggan.

\begin{abstract}
Development of transportation services in Indonesia is increasing every year, this is influenced by increasingly sophisticated technological developments. This rapid progress certainly has a significant impact, both positive and negative impacts on other business actors. The emergence of online transportation is able to undermine conventional business people, even though Blue Bird's transportation services are still able to survive amid the rapid competition in this globalization.

This study aims to determine how much influence Quality of service, Brand Image and Customer Satisfaction on Blue Bird Taxi Customer Loyalty. The type of research used is quantitative with accidental sampling technique, involving 105 respondents of Blue Bird taxi customers in the West Jakarta area. Data collection includes observation, questionnaires and literature studies. The analytical method used
\end{abstract}


is the validity test, reliability test, classic assumption test, multiple linear analysis and hypothesis testing.

Data processing using SPSS Version 22.0 and concluded that service quality (XI) does not have a positive influence with a significant value of 0.122 greater than 0.05 , Brand Image variable does not give a positive effect with a significant value of 0.192 greater than 0.05 and Customer Satisfaction variables gives a positive influence with a significant value of 0.002 smaller than 0.05 .

Keywords: Service Quality, Brand Image, Customer Satisfaction and Customer Loyalty

\section{PENDAHULUAN}

Transportasi merupakan sarana yang sangat penting dalam kehidupan dimasyarakat, setiap orang tentu membutuhkan transportasi dalam berbagai kegiatan untuk membantu kelancaran aktivitasnya. Semakin berkembangnya jasa transportasi yang ditawarkan saat ini, membuat konsumen sebagai pengambil keputusan menjadi lebih selective untuk memilih jasa transportasi yang akan digunakan, tidak hanya dari segi kemudahan, harga, dan sebab lainya, melainkan kualitas pelayanan yang baik merupakan hal yang amat penting dan dibutuhkan oleh konsumen [Razak et al., 2016].

Menghadapi persaingan yang cukup ketat, perusahaan modern akan selalu membangun nilai keuntungan yang akan didapatkan dari pelanggan melalui pembelian produk (customer value) untuk mencapai kepuasan pelanggan (customer satisfaction) sehingga akan berdampak pada kesetiaan pelanggan terhadap produk tersebut (customer loyalty) [Kotler, Philip and Keller, 2018].

Tabel 1. Daftar Armada Taksi Konvensional di Jakarta Dari Tahun 2017 s.d 2020

\begin{tabular}{lll}
\hline No & $\begin{array}{l}\text { Nama } \\
\text { Taksi }\end{array}$ & Armada \\
\hline 1 & Taxi & 12.000 menjadi 9.600 unit \\
& Express & \\
2 & Taxiku & 2.500 menjadi 100 unit \\
3 & Blue Bird & 29.000 unit \\
\hline
\end{tabular}

Sumber : https://finance.detik.com

Data tersebut menunjukkan adanya perubahan secara signifikan penurunan armada taksi konvensional express dan Taxiku. Penurunan ini dipengaruhi dengan adanya taksi online yang semakin marak, sedangkan Blue Bird masih mampu mempertahankan armadanya lebih banyak dibandingkan kedua taksi konvensional 
tersebut. Dengan adanya masalah-masalah dalam kasus ini, maka penulis tertarik melakukan penelitian dengan judul "Pengaruh Kualitas Pelayanan, Brand Image, Dan Kepuasan Pelanggan Terhadap Loyalitas Pelanggan Jasa Transportasi Taksi Blue Bird".

Berdasarkan fenomena diatas, maka penulis mengambil rumusan masalah sebagai berikut:

1) Apakah Kualitas Pelayanan yang baik akan berpengaruh terhadap Loyalitas pelanggan penggunaan jasa transportasi taksi Blue Bird?

2) Apakah Brand Image yang melekat pada sebuah bisnis usaha yang sudah cukup baik perpengaruh terhadap Loyalitas Pelanggan terhadap penggunaan jasa transportasi taksi Blue Bird?

3) Apakah Kepuasan Pelanggan akan berpengaruh terhadap Loyalitas Pelanggan penggunaan jasa transportasi taksi Blue Bird?

\section{TINJAUAN PUSTAKA DAN HIPOTESIS}

\section{A. Kualitas Pelayanan}

Kualitas pelayanan menurut pendapat [Normasari, 2013] merupakan perbandingan antara layanan yang dirasakan (persepsi) konsumen dengan kualitas layanan yang diharapkan konsumen. Berdasarkan pendapat tersebut dapat diketahui bahwa kualitas pelayanan yaitu memberikan kesempurnaan pelayanan untuk tercapainya keinginan atau harapan pelanggan.

[Setyowati, 2017] kualitas pelayanan adalah berbagai usaha yang dilakukan oleh perusahaan untuk memenuhi kebutuhan dan harapan para pelanggan. Lima dimensi utama yang disusun sesuai urutan tingkat kepentingan relatifnya yaitu: keadaan (reliabilitas), daya tanggap (responsiveness), jaminan (assurance), empati (empathy) dan bukti fisik (tangibles), [Jannah et al., 2018].

Reliability yaitu memberikan layanan sesuai janji, mempunyai kemampuan untuk mengatasi masalah layanan pelanggan, memberikan layanan yang benar sejak awal, memberikan layanan pada waktu yang telah dijanjikan, menjaga informasi akurat.

Responsiveness yaitu selalu memberitahu pelanggan kapan layanan akan diberikan, mengutamakan layanan ke pelanggan mempunyai kemauan untuk menolong pelanggan, selalu siap untuk merespon permintaan pelanggan. 
Assurance yaitu petugas yang dapat menumbuhkan rasa percaya diri pelanggan, membuat pelanggan merasa aman dalam bertransaksi, petugas yang selalu ramah, petugas yang mempunyai pengetahuan untuk menjawab pertanyaan pelanggan.

Emphaty yaitu memberikan perhatian secara individual, mendapatkan hati pelanggan, petugas yang mengerti kebutuhan pelanggan, dan jam kerja yang tepat dalam melayani pelanggan.

Tangibles yaitu peralatan modern, fasilitas visual yang menarik, petugas yang berpenampilan rapi, fasilitas pendukung yang berhubungan dengan layanan.

\section{B. Brand Image}

[Gedalia, 2015], sebagai sekumpulan asosiasi brand yang terbentuk di benak konsumen. Sejalan dengan itu, brand image sebagai persepsi konsumen tentang suatu merek sebagai refleksi dari asosiasi merek yang ada pada pikiran konsumen. Citra merupakan produk akhir dari sikap awal dan pengetahuan yang terbentuk lewat proses pengulangan yang dinamis karena pengalaman.

Citra merek terdiri dari tiga dimensi, yaitu:

Product attributes (Atribut produk) adalah fitur-fitur yang menjadi ciri deskriptif produk atau jasa apa yang dipikirkan konsumen tentang segala hal yang terlibat dalam suatu produk atau jasa dengan pembelian atau konsumsi seperti kemasan, isi produk, harga, rasa, dan lain-lain.

Consumer benefits (Keuntungan konsumen) adalah nilai pribadi yang dirasakan oleh konsumen terhadap atribut produk atau jasa dan apa yang bisa diberikannya.

Brand attitudes (Kepribadian merek) merupakan evaluasi keseluruhan mengenai kepribadian sebuah merek apabila merek tersebut diumpamakan manusia.

\section{Kepuasan Pelanggan}

[Kotler and Armstrong, 2018] Kepuasan konsumen terletak dari bagaimana performa penampilan produk untuk memenuhi harapan konsumen. Jika tidak sesuai dengan harapan konsumen, konsumen akan langsung tidak puas. Sebaliknya jika performa sesuai dengan [Setyowati, 2017] kepuasan pelanggan adalah suatu keadaan yang dirasakan oleh seseorang ketika apa yang dirasakan telah sesuai dengan 
harapanya. Kepuasan pelanggan dapat diidentifikasi dan dipantau dengan beberapa metode yaitu:

1. Metode Keluhan dan saran, dilakukan melalui kotak saran dan komentar. Keluhan-keluhan dari pelanggan ini dapat dijadikan sebagai sumber inspirasi bagi perusahaan untuk memperbaiki layanan.

2. Melakukan survey kepuasan pelanggan, melalui cara ini maka perusahaan dapat memperoleh respons langsung dari pelanggan.

3. Lost Customer Analysis, metode ini dilakukan dengan cara perusahaan melakukan penelitian pada pelanggan yang telah berhenti melakukan pembelian untuk mengetahui alasan mengapa mereka berhenti dan dapat mengetahui kelemahan produk tersebut.

4. Chost Shopping, metode ini dilakukan untuk membandingkan kelemahan dan kelebihan produk perusahaan dengan pesaing.

\section{Loyalitas Pelanggan}

Loyalitas Pelanggan Menurut [Gedalia, 2015]), definisi dari loyalitas konsumen adalah berbagai cara perusahaan sebagaimana pembeli supaya dapat kembali dan ada kemauan untuk menjadi bagian dari organisasi itu. Jadi perusahaan memang harus melakukan berbagai cara untuk mencapai tujuan akhir mereka yaitu loyalitas konsumen.

Selain itu juga suatu kecenderungan untuk membeli dan atau menggunakan lagi suatu produk atau jasa. Hal terpenting yang harus dilakukan untuk memenangkan persaingan adalah memuaskan konsumen. Karena konsumen merupakan pusat dari segala usaha yang dilakukan oleh perusahaan.

[Pi and Huang, 2011] menunjukan bahwa loyalitas pelanggan dapat diperlihatkan melalui sikap dan perilaku. Sikap termasuk niat pembelian kembali atau membeli produk lain dari perusahaan, niat untuk merekomendasikan dan kekebalan terhadap pesaing.

Menurut (Griffin 2009) dalam bagian yang dikutip oleh [Wendha et al., 2013] ada empat tahap loyalitas pelanggan jasa, diantaranya adalah sebagai berikut:

1. Loyalitas berdasarkan kesadaran (cognitive loyality) merasakan bahwa merk yang satu lebih disukai dari pada merk yang lain berdasarkan informasi atribut tentang 
merk yang diterimanya. Informasi yang dipegang oleh konsumen (keyakinan konsumen) harus menunjuk pada merek yang dianggap lebih superior dalam persaingan.

2. Loyalitas berdasarkan Pengaruh (affective Loyality) pada tingkat ini loyalitas memiliki tingkat kesukaan konsumen harus lebih tinggi dari pada merek saingan, baik dalam perilaku maupun komponen yang mempengaruhi kepuasan. Kondisi ini sangat sulit untuk dihilangkan karena kesetiaan sudah tertanam dalam pikiran konsumen bukan hanya sebagai kesadaran atau harapan.

3. Loyalitas berdasarkan Komitmen (conative loyality) tahap loyalitas ini mengandung komitmen perilaku yang tinggi dalam melakukan pembelian suatu jasa. Hasrat untuk melakukan pembelian ulang atau bersikap loyal merupakan tindakan yang dapat diantisipasi namun tidak disadari.

4. Loyalitas berdasarkan tindakan (action loyality) tahap ini merupakan tahapan terakhir dari kesetiaan. Tahap ini diawali dengan suatu keinginan yang disertai dengan motivasi, selanjutnya diikuti oleh siapapun untuk bertindak dan ingin untuk mengatasi seluruh hambatan untuk melakukan tindakan.

H1 : Kualitas pelayanan berpengaruh positif terhadap Loyalitas Pelanggan

H2 : Brand Image berpengaruh positif terhadap Loyalitas Pelanggan

H3 : Kepuasan Pelanggan berpengaruh positif terhadap Loyalitas Pelanggan 


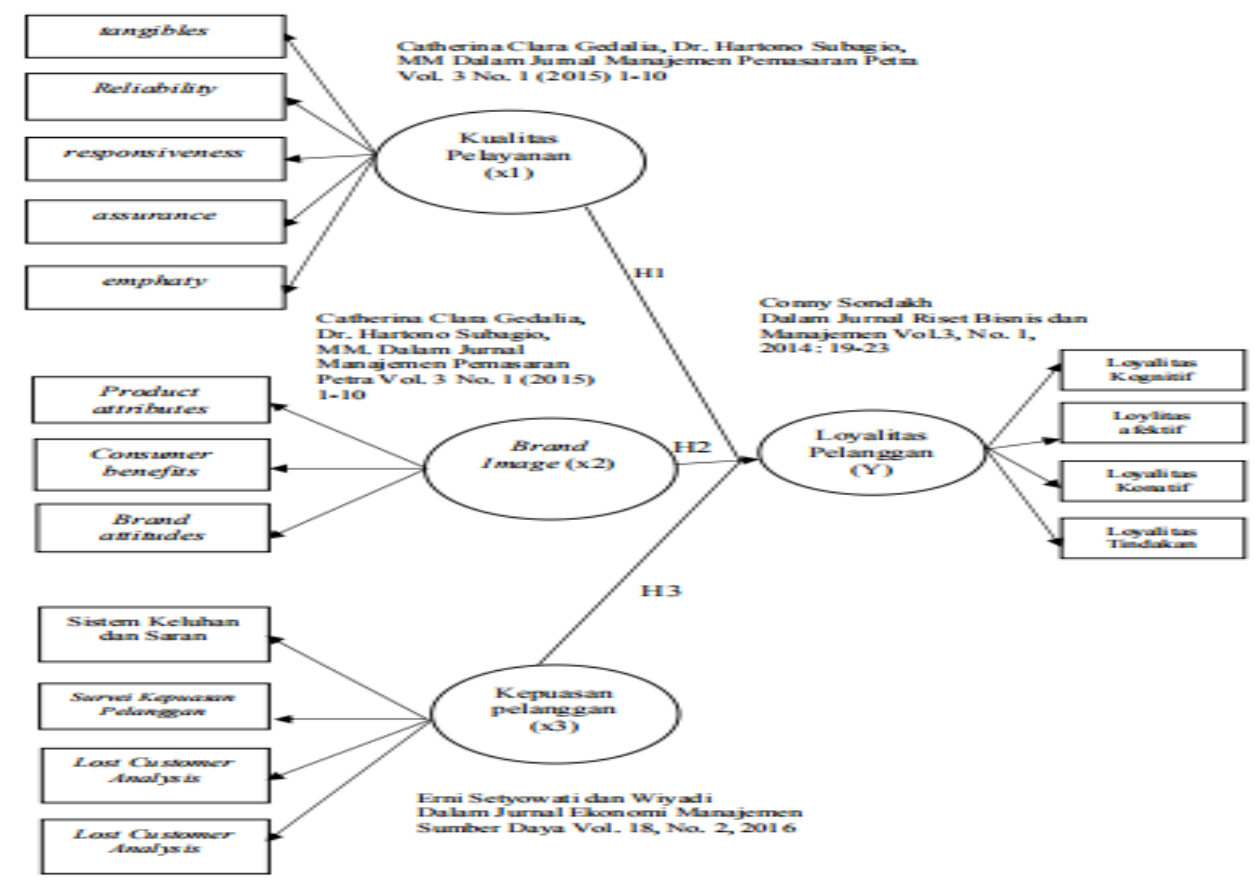

Gambar 1: Kerangka Konsep

\section{METODE PENELITIAN}

\section{A. Jenis Penelitian}

Penelitian ini menggunakan jenis penelitain Kuantitatif dengan memperoleh data yang berbentuk angka atau data kualitatif yang diangkakan, dengan metode nonprobability sampling dengan teknik accidental sampling yaitu teknik penentuan sample tanpa sengaja dengan mengambil sample yang kebetulan ditemui pada saat itu [Sugiyono, 2010], jenis penelitian ini dilakukan berdasarkan pada judul yang diteliti yaitu "Pengaruh Kualitas Pelayanan, Brand Image dan Kepuasan Pelanggan terhadap Loyalitas Pelanggan Jasa Transportasi Taksi Blue Bird (studi kasus di Mall Ciputra Jakarta Barat)".

\section{B. Populasi dan Sampel}

Populasi dalam penelitian ini adalah konsumen yang pernah menggunakan jasa transportasi taksi Blue Bird, metode penentuan sampel yang digunakan dalam penelitian ini adalah non probability sampling yaitu teknik pengambilan sampel yang tidak memberi peluang atau kesempatan sama bagi setiap unsur atau anggota populasi untuk dipilih menjadi sampel [Sugiyono, 2010]. 
Penarikan sampel pada penelitian ini akan menggunakan teknik accidental sampling yaitu teknik penentuan sample tanpa sengaja (accidental) dengan mengambil sample yang kebetulan ditemui pada saat itu dan cocok sebagai sumber data, serta pernah menggunakan jasa transportasi taksi Blue Bird, [Sugiyono, 2010].

Menurut [Roscoe, 1975] dalam [Sugiyono, 2010] cara menentukan jumlah sampel dalam penelitian yaitu:

1. Ukuran sampel yang layak dalam penelitian adalah antara 30 sampai 500 orang.

2. Bila sampel dibagi dalam kategori (misalnya: pria-wanita, pegawai negeri-swasta, dan lain-lain), maka jumlah anggota sampel setiap kategori minimal 30 orang.

3. Bila didalam penelitian akan melakukan analisis dengan multivariate (korelasi atau regresi ganda), maka jumlah anggota sampel minimal 10 kali dari jumlah variabel yang diteliti.

4. Untuk penelitian eksperimen yang sederhan, yang menggunakan kelompok eksperimen dan kelompok control, maka jumlah anggota sampel masing-masing antara 10 sampai 20.

Berdasarkan poin pertama yaitu ukuran sampel yang layak dalam penelitian adalah antara 30 sampai 500 orang maka penulis menetapkan sampel sebanyak 105 sampel sesuai dengan hasil penyebaran kuesioner, dan seluruh jumlah responden yang ditemui saat membagikan kuesioner.

\section{HASIL DAN PEMBAHASAN}

Bab ini akan membahas mengenai hasil penelitian studi lapangan yang dimulai dari statistik deskriptif yang berhubungan dengan data penelitian, meliputi gambaran umum responden, variabel penelitian, uji kualitas data, uji validitas, uji reliabilitas, asumsi klasik, yang meliputi uji normalitas, multikolinearitas, autokorelasi, dan heteroskedasitas, analisis regresi berganda, Koefisien Determinasi dan uji Hipotesis yaitu Uji T, yang diuji secara stasistik dengan menggunakan program SPSS versi 22.

\section{A. Uji Validitas}

Uji validitas digunakan untuk menguji sejauh mana ketepatan alat pengukur dapat mengungkapkan konsep gejala/kejadian yang diukur. Uji validitas digunakan untuk mengukur sah atau tidaknya suatu kuesioner. 
Uji validitas dihitung dengan membandingkan nilai $\mathrm{r}$ hitung (correlateditem-total correlation) yang diperoleh dari SPSS versi 22 dengan nilai $r$ table, jika $r$ hitung $>$ dari r table (pada taraf signifikansi 5\%) maka pernyataan tersebut dinyatakan valid. Dan jika nilai $\mathrm{r}$ hutung < dari $\mathrm{r}$ tabel maka pernyataan tersebut dinyatakan tidak valid. Dalam penelitian ini penulis mengambil sampel sebanyak 105 responden, sehingga dapat ditentukan $\mathrm{r}$ table adalah $0,1918(\mathrm{df}=\mathrm{N}-2) /(\mathrm{df}=105-2)$ dalam tolerance 0,05 atau $5 \%$.

1. Uji validitas Kualitas Pelayanan

Tabel 2. Uji validitas Kualitas Pelayanan

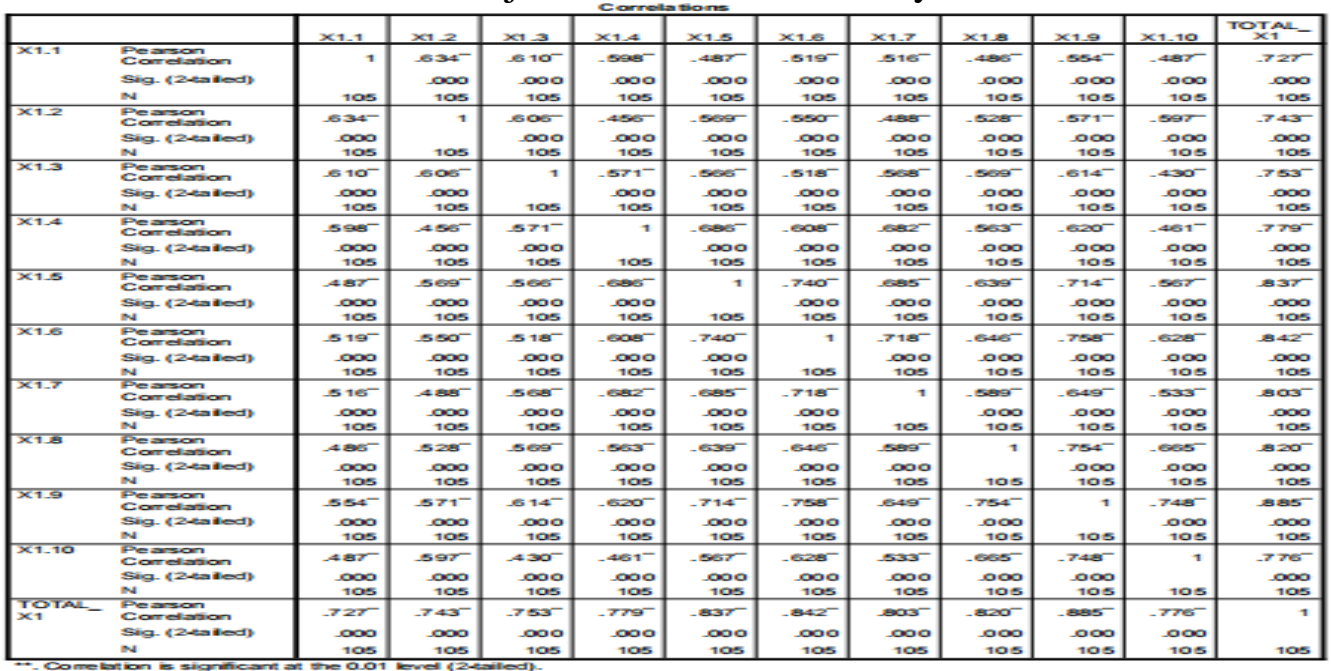

2. Uji validitas Brand Image

Tabel 3. Uji validitas Brand Image

\begin{tabular}{|c|c|c|c|c|c|c|c|c|c|c|}
\hline & & $x=1$ & $x \geq 2$ & $x \geq 3$ & $x \geq 4$ & $\times 2.5$ & $x=6$ & $\times 2.7$ & $x \geq a$ & TOTAL - \\
\hline$\times 121$ & $\begin{array}{l}\text { Pearson } \\
\text { Corretation } \\
\text { seg. (2-taited) } \\
\text { Ne }\end{array}$ & & $\begin{array}{r}-611- \\
-\infty 00 \\
105\end{array}$ & $\begin{array}{r}-492 \\
-\infty 00 \\
105\end{array}$ & $\begin{array}{r}553^{-} \\
.000 \\
105 \\
\end{array}$ & $\begin{array}{r}617- \\
1000 \\
105 \\
\end{array}$ & $\begin{array}{r}495^{-} \\
-000 \\
105\end{array}$ & $\begin{array}{r}.59 x^{-} \\
-\infty 00 \\
105\end{array}$ & $\begin{array}{r}.551- \\
000 \\
105 \\
\end{array}$ & $\begin{array}{l}.774 \\
000 \\
105\end{array}$ \\
\hline$x \geq 2$ & $\begin{array}{l}\text { Peascon } \\
\text { Darretation } \\
\text { Seg-(2-tailed) } \\
\text { N }\end{array}$ & $\begin{array}{r}611^{-} \\
000 \\
105\end{array}$ & 1 & $\begin{array}{r}-431- \\
-000 \\
105\end{array}$ & $\begin{array}{l}478- \\
000 \\
105\end{array}$ & $\begin{array}{r}.528- \\
.000 \\
105\end{array}$ & $\begin{array}{r}-507 \\
-000 \\
105\end{array}$ & $\begin{array}{r}592^{-} \\
-\infty 00 \\
105\end{array}$ & $\begin{array}{l}.528- \\
.000 \\
105\end{array}$ & $\begin{array}{l}-751- \\
.000 \\
105\end{array}$ \\
\hline$\times 23$ & $\begin{array}{l}\text { Peascinan } \\
\text { Darretation } \\
\text { seg. (2-tailed) } \\
\text { N }\end{array}$ & $\begin{array}{l}-492^{-} \\
000 \\
105\end{array}$ & $\begin{array}{r}-431^{-} \\
-000 \\
105\end{array}$ & $\begin{array}{r}1 \\
105\end{array}$ & $\begin{array}{l}-464- \\
.000 \\
105\end{array}$ & $\begin{array}{r}.502^{-} \\
.000 \\
105\end{array}$ & $\begin{array}{r}-485^{-} \\
-000 \\
105\end{array}$ & $\begin{array}{l}365- \\
-\infty 00 \\
105\end{array}$ & $\begin{array}{l}\text { 466 } \\
\text { वoo } \\
105\end{array}$ & $\begin{array}{l}65 \% \\
.000 \\
105\end{array}$ \\
\hline$\times 24$ & $\begin{array}{l}\text { Peansonion } \\
\text { Darretation } \\
\text { seg. (2-tained) } \\
\text { N }\end{array}$ & $\begin{array}{r}-553^{-} \\
000 \\
105\end{array}$ & $\begin{array}{r}-470^{-} \\
-\infty 00 \\
105\end{array}$ & $\begin{array}{r}-464 \\
-000 \\
105\end{array}$ & 105 & $\begin{array}{r}-751^{-} \\
000 \\
105\end{array}$ & $\begin{array}{r}-635^{-} \\
-000 \\
105\end{array}$ & $\begin{array}{r}-543^{-} \\
-\infty 00 \\
105\end{array}$ & $\begin{array}{r}.542 \\
.000 \\
105\end{array}$ & $\begin{array}{l}796 \\
000 \\
105\end{array}$ \\
\hline$\times 25$ & $\begin{array}{l}\text { Pearson } \\
\text { Oarretation } \\
\text { Seg-(2-tained) } \\
\text { N }\end{array}$ & $\begin{array}{r}617- \\
000 \\
105\end{array}$ & $\begin{array}{r}-520^{-} \\
-\infty 00 \\
105\end{array}$ & $\begin{array}{r}-502 \\
-\infty 00 \\
105\end{array}$ & $\begin{array}{r}751^{-} \\
.000 \\
105\end{array}$ & 105 & $\begin{array}{r}-728^{-} \\
-000 \\
105\end{array}$ & $\begin{array}{r}-612- \\
-\infty 00 \\
105\end{array}$ & $\begin{array}{c}\text {.896 } \\
\text {.000 } \\
105\end{array}$ & $\begin{array}{l}.865 \\
.000 \\
105\end{array}$ \\
\hline$\times 26$ & $\begin{array}{l}\text { Pearson } \\
\text { Corretation } \\
\text { Seg. (2-tailed) } \\
\mathbb{N}\end{array}$ & $\begin{array}{r}-495^{-} \\
000 \\
105 \\
\end{array}$ & $\begin{array}{r}-507 \\
-\infty 00 \\
105 \\
\end{array}$ & $\begin{array}{r}-485 \\
-\infty 00 \\
105\end{array}$ & $\begin{array}{r}635- \\
000 \\
105 \\
\end{array}$ & $\begin{array}{r}7288^{-} \\
.000 \\
105 \\
\end{array}$ & 105 & $\begin{array}{r}-595- \\
-\infty 00 \\
105 \\
\end{array}$ & $\begin{array}{r}.675 \\
.000 \\
105 \\
\end{array}$ & $\begin{array}{l}\text { 830 } \\
\text {.000 } \\
105\end{array}$ \\
\hline$\times 27$ & $\begin{array}{l}\text { Peascinon } \\
\text { Darretation } \\
\text { seg-(2-tained) } \\
\text { N }\end{array}$ & $\begin{array}{r}-893^{-} \\
000 \\
105\end{array}$ & $\begin{array}{r}-502^{-} \\
-\infty 00 \\
105\end{array}$ & $\begin{array}{r}-365 \\
-\infty 00 \\
105\end{array}$ & $\begin{array}{r}-543^{-} \\
000 \\
105 \\
\end{array}$ & $\begin{array}{r}612^{-} \\
.000 \\
105 \\
\end{array}$ & $\begin{array}{r}-305- \\
-000 \\
105 \\
\end{array}$ & 105 & $\begin{array}{r}.676 \\
.000 \\
105 \\
\end{array}$ & $\begin{array}{l}794 \\
.000 \\
105\end{array}$ \\
\hline$\times 28$ & $\begin{array}{l}\text { Peamson } \\
\text { Carretion } \\
\text { seg-(2-taized) } \\
\text { N }\end{array}$ & $\begin{array}{r}-561^{-} \\
000 \\
105\end{array}$ & $\begin{array}{r}-52 a^{-} \\
-\infty 00 \\
105\end{array}$ & $\begin{array}{r}-466 \\
-\infty 00 \\
105\end{array}$ & $\begin{array}{r}-542^{-} \\
.000 \\
105\end{array}$ & $\begin{array}{r}680^{-} \\
.000 \\
105 \\
\end{array}$ & $\begin{array}{r}-675^{-} \\
-000 \\
105\end{array}$ & $\begin{array}{r}-676- \\
-\infty 00 \\
105\end{array}$ & 105 & $\begin{array}{l}819^{-} \\
.000 \\
105\end{array}$ \\
\hline TOTAL_ & $\begin{array}{l}\text { Pearson } \\
\text { Corretation } \\
\text { seg-(2-taized) } \\
\text { N }\end{array}$ & $\begin{array}{r}-774^{-} \\
000 \\
105 \\
\end{array}$ & $\begin{array}{r}-751- \\
-\infty 00 \\
105 \\
\end{array}$ & $\begin{array}{r}657 \\
-\infty 00 \\
105\end{array}$ & $\begin{array}{r}-790^{-} \\
.000 \\
105 \\
\end{array}$ & $\begin{array}{r}\text { aes- } \\
\text {-0oo } \\
105 \\
\end{array}$ & $\begin{array}{r}830^{-} \\
-000 \\
105 \\
\end{array}$ & $\begin{array}{r}-794^{-1} \\
-\infty 00 \\
105\end{array}$ & $\begin{array}{r}19- \\
\text {-000 } \\
105\end{array}$ & 105 \\
\hline
\end{tabular}


3. Uji validitas Kepuasan Pelanggan

Tabel 4. Uji validitas Kepuasan Pelanggan

\begin{tabular}{|c|c|c|c|c|c|c|c|c|c|}
\hline & & $\times 3.1$ & $\times 3.2$ & $\times 3.3$ & $\times 3.4$ & $\times 3.5$ & $\times 3.6$ & $\times 3.7$ & $\begin{array}{c}\text { TOTALL } \\
\times 3\end{array}$ \\
\hline$\times 3.1$ & $\begin{array}{l}\text { Pearson } \\
\text { Correla tion } \\
\text { Siad. } 12 \text {-tailledis } \\
\text { N }\end{array}$ & $\begin{array}{r}1 \\
105\end{array}$ & $\begin{array}{r}791^{-} \\
-000 \\
105\end{array}$ & $\begin{array}{r}688^{-} \\
-000 \\
105\end{array}$ & $\begin{array}{r}610^{-} \\
.000 \\
105\end{array}$ & $\begin{array}{r}561^{-} \\
.000 \\
105\end{array}$ & $\begin{array}{l}-560^{-} \\
.000 \\
105\end{array}$ & $\begin{array}{r}.655 \\
.000 \\
105\end{array}$ & $\begin{array}{r}821 \\
.000 \\
105\end{array}$ \\
\hline$\times 3.2$ & $\begin{array}{l}\text { Pearson } \\
\text { Correla tion } \\
\text { Sig- (2-tailed) } \\
\text { N }\end{array}$ & $\begin{array}{r}791- \\
-000 \\
105\end{array}$ & $\begin{array}{r}1 \\
105 \\
\end{array}$ & $\begin{array}{r}720- \\
-000 \\
105 \\
\end{array}$ & $\begin{array}{r}638 \\
.000 \\
105\end{array}$ & $\begin{array}{r}590 \\
.000 \\
105\end{array}$ & $\begin{array}{l}-508 \\
.000 \\
105 \\
\end{array}$ & $\begin{array}{r}644 \\
.000 \\
105 \\
\end{array}$ & $\begin{array}{l}826 \\
000 \\
105\end{array}$ \\
\hline$\times 3.3$ & $\begin{array}{l}\text { Pearson } \\
\text { Correla tion } \\
\text { Sig- (2-tailled) } \\
\text { N }\end{array}$ & $\begin{array}{r}68: 8- \\
-000 \\
105 \\
\end{array}$ & $\begin{array}{r}720- \\
-000 \\
105 \\
\end{array}$ & $\begin{array}{r}1 \\
105 \\
\end{array}$ & $\begin{array}{r}722- \\
-000 \\
105 \\
\end{array}$ & $\begin{array}{r}702- \\
.000 \\
105\end{array}$ & $\begin{array}{r}1653^{-} \\
.000 \\
105 \\
\end{array}$ & $\begin{array}{r}-7100 \\
-000 \\
105 \\
\end{array}$ & $\begin{array}{l}886 \\
100 \\
105 \\
\end{array}$ \\
\hline$\times 3.4$ & $\begin{array}{l}\text { Pearrson } \\
\text { Correla tion } \\
\text { Sag- (2-tailed) } \\
\text { N }\end{array}$ & $\begin{array}{r}610^{-} \\
-000 \\
105 \\
\end{array}$ & $\begin{array}{r}638- \\
-000 \\
105 \\
\end{array}$ & $\begin{array}{r}722- \\
-000 \\
105 \\
\end{array}$ & $\begin{array}{r}1 \\
105 \\
\end{array}$ & $\begin{array}{r}731^{-} \\
000 \\
105\end{array}$ & $\begin{array}{l}.670^{-} \\
-000 \\
105 \\
\end{array}$ & $\begin{array}{r}-675 \\
.000 \\
105 \\
\end{array}$ & $\begin{array}{l}858- \\
.000 \\
105\end{array}$ \\
\hline$\times 3.5$ & $\begin{array}{l}\text { Pearson } \\
\text { Correla tion } \\
\text { Sia. - } 22 \text {-tailled, } \\
\text { N }\end{array}$ & $\begin{array}{r}-561^{-} \\
-000 \\
105 \\
\end{array}$ & $\begin{array}{r}-509^{-} \\
-000 \\
105 \\
\end{array}$ & $\begin{array}{r}.702^{-} \\
-000 \\
105 \\
\end{array}$ & $\begin{array}{r}731- \\
-900 \\
105 \\
\end{array}$ & $\begin{array}{r}1 \\
105 \\
\end{array}$ & $\begin{array}{l}.642^{-} \\
.000 \\
105 \\
\end{array}$ & $\begin{array}{r}677 \\
000 \\
105 \\
\end{array}$ & $\begin{array}{l}837 \\
.000 \\
105\end{array}$ \\
\hline$\times 3.6$ & $\begin{array}{l}\text { Pearsoon } \\
\text { Correla tion } \\
\text { Sag- (2-tailled) } \\
\text { N }\end{array}$ & $\begin{array}{r}-560^{-} \\
-000 \\
105 \\
\end{array}$ & $\begin{array}{r}508^{-} \\
-000 \\
105 \\
\end{array}$ & $\begin{array}{r}653^{-} \\
-000 \\
105 \\
\end{array}$ & $\begin{array}{r}679^{-} \\
-000 \\
105 \\
\end{array}$ & $\begin{array}{r}642- \\
.000 \\
105 \\
\end{array}$ & 105 & $\begin{array}{r}623 \\
.000 \\
105 \\
\end{array}$ & $\begin{array}{l}181^{-1} \\
000 \\
105\end{array}$ \\
\hline$\times 3.7$ & $\begin{array}{l}\text { Pearson } \\
\text { Correla tion } \\
\text { Sig- (2-tailed) } \\
\text { N }\end{array}$ & $\begin{array}{r}655^{-} \\
.000 \\
105 \\
\end{array}$ & $\begin{array}{r}644^{-} \\
-000 \\
105 \\
\end{array}$ & $\begin{array}{r}710^{-} \\
-000 \\
105 \\
\end{array}$ & $\begin{array}{r}.675 \\
.000 \\
105 \\
\end{array}$ & $\begin{array}{r}677 \\
100 \\
105 \\
\end{array}$ & $\begin{array}{r}623- \\
.000 \\
105 \\
\end{array}$ & $\begin{array}{r}1 \\
105 \\
\end{array}$ & $\begin{array}{l}850^{-} \\
000 \\
105 \\
\end{array}$ \\
\hline $\begin{array}{l}\text { TOTAL_L } \\
\times 3^{-1}\end{array}$ & $\begin{array}{l}\text { Pearson } \\
\text { Correla tion } \\
\text { Sag- (2-tailled) } \\
\text { N }\end{array}$ & $\begin{array}{r}821- \\
-000 \\
105 \\
\end{array}$ & $\begin{array}{r}826^{-} \\
-000 \\
105 \\
\end{array}$ & $\begin{array}{r}886^{-} \\
-000 \\
105\end{array}$ & $\begin{array}{r}858 \\
-000 \\
105 \\
\end{array}$ & $\begin{array}{r}837 \\
.000 \\
105\end{array}$ & $\begin{array}{r}801^{-} \\
.000 \\
105 \\
\end{array}$ & $\begin{array}{r}850^{-} \\
.000 \\
105 \\
\end{array}$ & $\begin{array}{r}1 \\
105 \\
\end{array}$ \\
\hline
\end{tabular}

4. Uji validitas Loyalitas Pelanggan

Tabel 5. Uji validitas Loyalitas Pelanggan

\begin{tabular}{|c|c|c|c|c|c|c|c|c|c|c|c|}
\hline & & $r=1$ & $r=2$ & 2.3 & $r=4$ & $r=5$ & $r=$ & $r=\pi$ & $r a$ & $r=$ & काan \\
\hline & 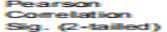 & & $-700-$ & 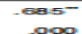 & $610-$ & -610 & $635-$ & $\operatorname{sen}$ & $60^{-}$ & $62-$ & $\infty$ \\
\hline & $\sim$ & 100 & 100 & $\begin{array}{l}+\infty \\
100\end{array}$ & $-\infty \infty$ & 100 & $+\infty \infty$ & $-\infty \infty$ & .000 & 100 & - wos \\
\hline 2.2 & Darsinion & $-\pi \times 4-$ & & $-720^{-}$ & $-633^{-}$ & $-35 s^{-1}$ & $\operatorname{sen}-$ & $480^{-}$ & $572^{-}$ & $5 \operatorname{sen}$ & त्रूम \\
\hline & $n$ & 100 & 105 & 100 & 100 & 100 & 100 & $\$ 100$ & 100 & 1000 & $-\infty 00$ \\
\hline & Darnesion & - & $-720-$ & & $-\infty$ & $-\infty 00-$ & $728-$ & $-705-$ & $638^{-}$ & 705 & 80 \\
\hline & N & 105 & 100 & 105 & 105 & 100 & 105 & .00 & 100 & -100 & $\begin{array}{l}-\infty \\
-105\end{array}$ \\
\hline 4 & Darnonim & - $61 \mathrm{e}^{-}$ & $-63^{-}$ & $82-$ & & $755^{-}$ & $8 \infty \infty^{-}$ & $\infty e^{-}$ & $60 e^{-}$ & $700-$ & as:- \\
\hline & $N-2-2 a d b$ & 100 & .00 & 100 & 105 & 100 & 100 & 100 & 100 & 100 & $-\infty 05$ \\
\hline 5 & Earsinton & san- & $-5 \times 5-$ & $-\infty 0^{-}$ & -75s- & $=$ & an- & $754^{-}$ & $63 a^{-}$ & $7 \mathrm{~m}^{-}$ & ase- \\
\hline & & & & & 105 & 105 & 100 & & 100 & 100 & mos \\
\hline & Dearson: & $35^{-}$ & $50 e^{-}$ & $72 a^{-}$ & $00=-$ & & & & $7 \infty^{-}$ & & 395- \\
\hline & $s=0-2-\sin \alpha$ & $\infty \infty$ & $\infty \infty$ & $-\infty$ & $-\infty \infty$ & $-\infty \infty$ & & $\infty$ & $\infty$ & 0 & $\infty$ \\
\hline & Nearon & 100 & $890-$ & 72 & 105 & 16 & 100 & & 105 & & 105 \\
\hline & 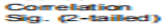 & $-\infty, 0$ & 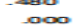 & -000 & $\infty$ & $-\infty \infty$ & -000 & & -000 & $-0 \infty$ & $\infty$ \\
\hline & Near & 105 & 100 & 105 & 105 & 105 & 5 & 100 & 105 & 105 & 105 \\
\hline & s-prend & 6000 & 1000 & $638-$ & 10000 & $-\infty 3^{-1}$ & $-\infty \infty$ & .000 & & $-\infty, 00$ & $\infty$ \\
\hline & Nas & 105 & 105 & 105 & 105 & & 10 & 105 & 105 & 105 & 105 \\
\hline & sogrential & $-\infty 0^{-1}$ & $-\infty, 1$ & $-757-$ & $-\infty$ & $\begin{array}{r}-7100 \\
-000\end{array}$ & 000 & 000 & $-\infty$, & & $\infty$ \\
\hline זI & Nearson & 105 & & 105 & 105 & 105 & 105 & 105 & 105 & 105 & 105 \\
\hline$=$ & couranes & $80 \mathbf{3}^{-}$ & $\operatorname{mea} \mathbf{a}^{-}$ & $80-$ & 8 & 85 & 8so- & $873^{-}$ & 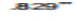 & & $=$ \\
\hline & 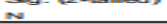 & & & 100 & 100 & 100 & 100 & 100 & 100 & 100 & tos \\
\hline
\end{tabular}

\section{B. Uji Reliabilitas}

Suatu kuesioner dikatakan reliable atau handal jika jawaban seseorang terhadap pernyataan adalah konsisten atau stabil dari waktu ke waktu.

Data dikatakan reliable apabila nilai cronbach's Alpha $>0,6$ dari masing-masing variabel. Berikut adalah hasil uji Reliabilitas masing-masing variabel, dengan menggunakan program SPSS versi 22. 
Tabel 6. Hasil Uji Realibilitas Kualitas Pelayanan

\begin{tabular}{|c|c|}
\hline Cronbach's Alpha & N of Items \\
\hline .936 & 10 \\
\hline
\end{tabular}

Sumber: hasil pengolahan data, 2019

Tabel 7. Hasil Uji Realibilitas Brand Image

\begin{tabular}{|c|c|}
\hline Cronbach's Alpha & N of Items \\
\hline 912 & 8 \\
\hline
\end{tabular}

Sumber: hasil pengolahan data, 2019

Tabel 8. Hasil Uji Realibilitas Kepuasan Pelanggan

\begin{tabular}{|c|c|}
\hline Cronbach's Alpha & N of Items \\
\hline .930 & 7 \\
\hline
\end{tabular}

Sumber: hasil pengolahan data, 2019

Tabel 9. Hasil Uji Realibilitas Loyalitas Pelanggan

\begin{tabular}{|c|c|}
\hline Cronbach's Alpha & N of Items \\
\hline .954 & 9 \\
\hline
\end{tabular}

\section{Uji Hipotesis dengan Uji T}

Uji T digunakan untuk menguji signifikasi hubungan antara variabel $\mathrm{X}$ dan $\mathrm{Y}$, apakah variabel X1, X2, X3 (Kualitas Pelayanan, Brand Image dan Kepuasan Pelanggan) benar-benar berpengaruh terhadapa variabel Y (Loyalitas Pelanggan) secara terpisah atau parsial.

Hipotesis yang digunakan dalam pengujian ini adalah:

Ho : Variabel-variabel bebas yaitu Kualitas Pelayanan, Brand Image dan Kepuasan

Pelanggan tidak mempunyai pengaruh yang signifikan terhadap variabel terikat yaitu Loyalitas Pelanggan.

Ha : Variabel-variabel bebas yaitu Kualitas Pelayanan, Brand Image dan Kepuasan Pelanggan mempunyai pengaruh yang signifikan terhadap variabel terikat yaitu Loyalitas Pelanggan.

Dasar pengambilan keputusan [Ghozali, 2011] adalah menggunakan angka probabilitas signifikasi, yaitu :

1. Apabila angka probabilitas signifikasi $<0,05$, maka Ho diterima dan Ha ditolak. 
2. Apabila angka probabilitas signifikasi $>0,05$, maka Ho ditolak dan Ha diterima.

Membandingkan nilai $\mathrm{T}$ hitung dengan $\mathrm{T}$ tabel

1. Apabila $\mathrm{T}$ tabel $>\mathrm{T}$ hitung, maka Ho diterima dan Ha ditolak.

2. Apabila $\mathrm{T}$ tabel $<\mathrm{T}$ hitung, maka Ho ditolak dan Ha diterima.

Tabel 10. Hasil Uji Hipotesis dengan Uji T

\begin{tabular}{|c|c|c|c|c|c|}
\hline \multirow{2}{*}{ Model } & \multicolumn{2}{|c|}{$\begin{array}{l}\text { Unstandardized } \\
\text { Coefficients }\end{array}$} & \multirow{2}{*}{$\begin{array}{c}\text { Standardized } \\
\text { Coefficients } \\
\text { Beta }\end{array}$} & \multirow{2}{*}{$\mathrm{T}$} & \multirow{2}{*}{ Sig. } \\
\hline & B & $\begin{array}{l}\text { Std. } \\
\text { Error }\end{array}$ & & & \\
\hline 1 (Constant) & -5.060 & 3.084 & & -1.641 & .104 \\
\hline Kualitas Pelayanan (X1) & .267 & .171 & .224 & 1.558 & .122 \\
\hline Brand Image (X2) & .267 & .204 & .178 & 1.312 & .192 \\
\hline Kepuasan Pelanggan (X3) & .645 & .205 & .404 & 3.150 & .002 \\
\hline
\end{tabular}

Sumber: hasil pengolahan data, 2019

Dari hasil output yang disajikan dalam tabel 5.22 dengan pengolahan data menggunakan SPSS Versi 22 dan Membandingkan nilai $\mathrm{T}$ hitung dengan $\mathrm{T}$ tabel dengan menggunakan rumus $\mathrm{T}$ tabel

$\mathrm{T}=\alpha ; \mathrm{n}-\mathrm{k}$

Dimana $\alpha=5 \%$ dan $\mathrm{n}=105$ Responden dan $\mathrm{k}=$ Jumlah Variabel $\mathrm{X}$ maka $\mathrm{T}=0,05$; $(105-3)=102$.

Jadi nilai T tabel untuk $\alpha 0.05$ dan df 102 yaitu $\mathbf{1 , 6 5 9 9 3 0}$ maka dapat ditarik kesimpulan bahwa:

1. Kualitas Pelayanan (X1) memiliki nilai signifikan $0,122>0.05$ dan T hitung 1,558

$<$ 1,659930 maka Kualitas Pelayanan tidak berpengaruh positif dan signifikan secara parsial terhadap Loyalitas Pelanggan. Maka untuk penelitian ini Ho diterima dan Ha ditolak.

2. Brand Image (X3) memiliki nilai signifikan $0,192>0,05$ dan $\mathrm{T}$ hitung $1,312<$ 1,659930 yang artinya Brand Image secara langsung tidak berpengaruh positif dan signifikan secara parsial terhadap Loyalitas Pelanggan. Maka untuk penelitian ini Ho diterima dan Ha ditolak. 
3. Kepuasan Pelanggan memiliki nilai sig 0,002 <0,05 dan $\mathrm{T}$ hitung $3.150>$ 1,659930 maka variabel Kepuasan Pelanggan memiliki Pengaruh positif dan signifikanterhadap Loyalitas Pelanggan. Maka pada variabel X3 Ha diterima dan Ho ditolak.

\section{PEMBAHASAN}

Berdasarkan hasil analisis pada SPSS ver. 22.0 yang dilakukan oleh peneliti, yang disajikan dengan menggunakan tabel dan pembahasannya menyatakan bahwa dari ketiga hipotesis yang dipaparkan oleh peneliti dalam bab sebelumnya bisa diterima.

\section{Pengaruh Kualitas Pelayanan terhadap Loyalitas Pelanggan}

Hasil pengujian hipotesis bias membuktikan bahwa kualitas pelayanan tidak berpengaruh terhadap Loyalitas Pelanggan, hal ini bisa dibuktikan dengan hasil olah data menggunakan SPSS Versi 22 yang menyatakan bahwa variabel Kualitas Pelayanan $(\mathrm{X} 1)$ diperoleh $\mathrm{T}$ hitung $=1,558<\mathrm{T}$ tabel 1,659930 dan tingkat signifikan yang dihasilkan 0,122 >0,05 yang artinya Ho diterima dan Ha ditolak, dengan demikian hipotesis pertama ditolak. Didukung oleh penelitian Selvy Normasari, et al dalam Jurnal Administrasi Bisnis (JAB) Vol.6 No.2 Desember 2013. Menghasilkan kesimpulan bahwa Kualitas Pelayanan tidak berpengaruh positif dan signifikan terhadap Loyalitas Pelanggan jasa transportasi taksi Blue Bird di Mall Ciputra Jakarta Barat.

\section{Pengaruh Brand Image terhadap Loyalitas Pelanggan}

Hasil pengujian hipotesis bias membuktikan bahwa Brand Image tidak berpengaruh terhadap Loyalitas Pelanggan, hal ini bisa dibuktikan dengan hasil olah data menggunakan SPSS Versi 22 yang menyatakan bahwa variabel Brand Image $(\mathrm{X} 2)$ diperoleh $\mathrm{T}$ hitung $=1,312<\mathrm{T}$ tabel 1,659930 dan tingkat signifikan yang dihasilkan 0,192 > 0,05 yang artinya Ho diterima dan Ha ditolak, dengan demikian hipotesis kedua ditolak. Didukung oleh penelitian Dewi Kurniawati, et al dalam JAB Vol. 14 No.2 September tahun 2014. Menghasilkan kesimpulan bahwa Brand Image tidak berpengaruh positif dan signifikan terhadap Loyalitas Pelanggan jasa transportasi taksi Blue Bird di Mall Ciputra Jakarta Barat. 


\section{Pengaruh Kepuasan Pelanggan terhadap Loyalitas Pelanggan}

Hasil pengujian hipotesis bias membuktikan bahwa Kepuasan Pelanggan berpengaruh terhadap Loyalitas Pelanggan, hal ini bisa dibuktikan dengan hasil olah data menggunakan SPSS Versi 22 yang menyatakan bahwa variabel kualitas pelayanan (X3) diperoleh $\mathrm{T}$ hitung $=3,150>\mathrm{T}$ tabel 1,659930 dan tingkat signifikan yang dihasilkan 0,002 <0,05 yang artinya Ho ditolak dan Ha diterima, dengan demikian hipotesis ketiga diterima

\section{SIMPULAN}

Berdasarkan analisis dan pembahasan terhadap hasil penelitian yang dilakukan dimana penulis menuliskan hipotesis inti dapat diambil kesimpulan sebagai berikut:

1. Kualitas Pelayanan dinyatakan tidak memiliki pengaruh positif dan signifikan terhadap variabel Loyalitas Pelanggan jasa transportasi taksi Blue Bird di mall Ciputra Jakarta Barat. hasil penelitian ini didukung oleh penelitian terdahulu oleh [Kumadji, 2013] dalam Jurnal Administrasi Bisnis (JAB) Vol.6 No.2 Desember 2013. Menghasilkan kesimpulan bahwa Kualitas Pelayanan tidak berpengaruh positif dan signifikan terhadap Loyalitas Pelanggan jasa transportasi taksi Blue Bird di Mall Ciputra Jakarta Barat.

2. Brand Image secara langsung tidak memiliki pengaruh positif dan signifikan terhadap Loyalitas Pelanggan jasa transportasi taksi Blue Bird di mall Ciputra Jakarta Barat. Hasil penelitian ini didukung oleh penelitian terdahulu aitu [Suwandi, 2020] JEAM Vol XIV April 2015.

3. Kepuasan Pelanggan memiliki Pengaruh positif dan signifikan terhadap Loyalitas Pelanggan jasa transportasi taksi Blue Bird di mall Ciputra Jakarta Barat. Hal ini sudah dibuktikan pada penelitian terdahulu oleh [Normasari, Selvy; Kumadji, Srikandi; Kusumawati, 2013] dalam Jurnal Administrasi Bisnis (JAB) Vol.6 No.2 Desember 2013.

Maka dari 3 variabel $\mathrm{X}$ pada penelitian ini yang berpengaruh positif dan signifikan terhadap Loyalitas Pelanggan jasa transportasi taksi Blue Bird adalah variabel Kepuasan Pelanggan. Denga demikian ketika perusahaan mampu memberikan Kepuasan Pelanggan kepada pelangganya maka akan mampu juga menumbuhkan sikap Loyal dari Pelanggan terhadap Perusahaan. 


\section{DAFTAR PUSTAKA}

Gedalia CC. 2015. Pengaruh Kualitas Layanan Dan Brand Image Terhadap Loyalitas Konsumen Dengan Kepuasan Konsumen Sebagai Variabel Intervening (Studi Kasus Monopole Coffee Lab Surabaya). J. Strateg. Pemasar. 3: 1 - 10.

Ghozali I. 2011. AplikasiMultivariatedengan Program IBM SPSS 19. 5 E, editor. Semarang: Badan Penerbit Universitas Diponegoro.

Jannah EN, Sudaryanto, Wulandari GA. 2018. Pengaruh Kualitas Layanan dan Brand Image Terhadap Loyalitas Melalui Kepuasan Pelanggan Matahari Department Store di Jember. UNEJ e-Proceding: 339 - 350.

Kotler, Philip and Keller K. 2018. Marketing Management. New Jersey. 211 - 220 p.

Kotler P, Armstrong G. 2018. Principles of Marketing (Electronic Version). 1 - 736 p.

Kumadji S. 2013. Jurnal Administrasi Bisnis (JAB). 6: 1 - 9.

Normasari, Selvy; Kumadji, Srikandi; Kusumawati A. 2013. PENGARUH KUALITAS PELAYANAN TERHADAP KEPUASAN PELANGGAN, CITRA PERUSAHAAN DAN LOYALITAS PELANGGAN. J. Adm. Bisnis: 1 - 9.

Normasari S. 2013. PENGARUH KUALITAS PELAYANAN TERHADAP KEPUASAN PELANGGAN, CITRA PERUSAHAAN DAN LOYALITAS PELANGGAN Survei padaTamu Pelanggan yang Menginap di Hotel Pelangi Malang. J. Adm. Bisnis S1 Univ. Brawijaya 6: 77767.

Pi W, Huang H. 2011. Effects of promotion on relationship quality and customer loyalty in the airline industry: The relationship marketing approach. African J. Bus. Manag. 5: $4403-4414$.

Razak I, Nirwanto N, Triatmanto B. 2016. The Impact of Product Quality and Price on Customer Satisfaction with the Mediator of Customer Value. J. Mark. Consum. Res. 30: $59-68$.

Roscoe JT. 1975. Fundamental research statistics for the behavioural sciences. New York: Holt Rinehart \& Winston.

Setyowati E. 2017. Pengaruh Kualitas Pelayanan, Harga, Dan Citra Merek Terhadap Loyalitas Pelanggan Dengan Kepuasan Pelanggan Sebagai Variabel Pemediasi. J. Manaj. Dayasaing 18: 102.

Sugiyono. 2010. Statistika Untuk Penelitian. Bandung: Alfabeta.

Suwandi. 2020. View metadata, citation and similar papers at core.ac.uk. J. Ekon. Akunt. dan Manaj. XIV: 274 - 282.

Wendha AAAAP, Rahyuda IK, Suasana IGA. 2013. Terhadap Kepuasan Dan Loyalitas Pelanggan Garuda Indonesia Di Denpasar. J. Manajemen, Strateg. Bisnis, dan Kewirausahaan 7: $19-28$. 